Board of Governors of the Federal Reserve System

International Finance Discussion Papers

Number 571

November 1996

\title{
IMPLICATIONS OF ECONOMIC INTERDEPENDENCE AND EXCHANGE RATE POLICY ON ENDOGENOUS WAGE INDEXATION DECISIONS
}

Jay H. Bryson, Chih-huan Chen, and David D. VanHoose

NOTE: International Finance Discussion Papers are preliminary materials circulated to stimulate discussion and critical comment. References in publications to International Finance Discussion Papers (other than an acknowledgment that the writer has had access to unpublished material) should be cleared with the author or authors. 


\begin{abstract}
This paper shows how economic interdependence affects wage indexation decisions when monetary authorities do not observe stochastic disturbances. Under a managed exchange rate, atomistic wage setters in interdependent nations will choose the same degree of indexation as they would in a small open economy. Under a flexible exchange rate, the likelihood rises that they will choose a lower degree of indexation than their counterparts in a small open economy as the degree of interdependence rises, as the variance of money demand shocks rise relative to supply shocks, and as supply curves steepen. Finally, wage indexation choices are more likely to be strategic complements as the degree of interdependence rises and as the variance of money demand shocks rises relative to supply shocks.
\end{abstract}




\title{
Implications of Economic Interdependence and Exchange Rate Policy on Endogenous Wage indexation Decisions
}

\author{
Jay H. Bryson, Chih-huan Chen, and David D. VanHoose ${ }^{1}$
}

\section{Introduction}

A labor-market assumption often employed in many open economy models is that nominal wages are fixed by contracts in advance of policy decisions. However, labor market contracts often permit some flexibility of nominal wages through explicit and implicit forms of nominal wage indexation. Because it is now well established that endogenous wage indexation potentially can have important macroeconomic implications, the omission of wage indexation from models of open economies is hardly academic. Nevertheless, to our knowledge there has been no effort to date to consider endogenous indexation in interdependent economies. ${ }^{2}$ The reason for this may be, as VanGompel (1994) has speculated and as we verify below, that computing equilibrium indexation choices in a two-country framework can be a difficult proposition.

This paper has two basic goals. The first goal is to extend the analysis on endogenous wage indexation from the framework of a small open economy to that of interdependent economies. We demonstrate that when authorities determine monetary policies before the

\footnotetext{
1 The authors are respectively: Economist, Division of Intemational Finance, Board of Govemors of the Federal Reserve System; Graduate Student, University of Alabama; Professor of Economics, University of Alabama. We are grateful for comments and suggestions that we have received from Daniel Arce, Joseph Daniels, Dale Henderson, Gian-Maria Milesi-Ferretti, Iannis Moumouras, Paul Pecorino, Bo Sandemann Rasmussen, and participants in the Macroeconomics Workshop at the University of Alabama. Any errors are ours. This paper represents the views of the authors and should not be interpreted as reflecting the views of the Board of Govemors of the Federal Reserve System or other members of its staff.

${ }^{2}$ The seminal works on the theory of wage indexation are Gray (1976) and Fischer (1977). Recent studies of wage indexation in closed-economy settings include Fethke and Jackman (1984), VanHoose and Waller (1989, 1991), Duca and VanHoose (1991), Ball and Cecchetti (1992), and Milesi-Ferretti (1994). Analyses of wage indexation in small open economies are provided by Aizenman (1985), Aizenman and Frenkel (1985), Flood and Marion (1982), Hardouvelis (1987, 1992), Marston (1982), Rasmussen (1993), and Zandamela (1988).
} 
realization of stochastic disturbances, atomistic wage setters in interdependent economies that are linked by a managed exchange rate will choose the same degree of wage indexation that they would in a small open economy. A flexible exchange rate will cause interdependent wage setters to choose degrees of indexation that, in general, differ from those chosen in a small open economy. Specifically, as the degree of interdependence rises, as the variance of money demand shocks rise relative to supply shocks, and as aggregate supply curves steepen, it becomes more likely that wage setters in interdependent economies will choose lower degrees of wage indexation than their counterparts in small open economies.

The second goal of the paper is to analyze the strategic interactions between indexation choices by wage setters of interdependent nations. We demonstrate that although wage indexation choices under a flexible exchange rate may be either strategic complements or strategic substitutes, strategic complementarity becomes more likely as the degree of interdependence rises and as the variance of foreign money demand shocks rise relative to supply shocks. ${ }^{3}$

The organization of the paper is as follows: A model of a small open economy and a model of interdependent economies are presented in Sections 2 and 3, respectively. Section 4 derives the authorities' optimal policy choices, and Section 5 evaluates optimal wage indexation choices. Section 6 summarizes the results and offers some final observations.

\section{A Small Open Economy Model}

The distinguishing feature of a small open economy (SOE) model is that the price of the single traded good that is produced by domestic firms is determined in the world market.

\footnotetext{
3 Strategic complementarity in wage indexation exists when an exogenous rise in foreign (domestic) indexation leads to an endogenous increase in domestic (foreign) indexation. Indexation decisions are strategic substitutes when an exogenous rise in foreign (domestic) indexation causes an endogenous decline in domestic (foreign) indexation.
} 
The market for this good is competitive and, following Ball (1988) and Waller and VanHoose (1992), domestic firms are uniformly distributed over the interval $i=0$ to $i=1$. Each firm has a pool of immobile workers who supply labor inelastically. As in Fischer (1977) and Gray (1976), nominal wage contracts at each firm set the base wage equal to the expected value of the Walrasian, market-clearing wage, but domestic wages are indexed to domestic prices.

The structure of the SOE model is as follows:

$$
\begin{aligned}
& \text { (1a) } y_{i}=\alpha\left(1-b_{i}\right)\left(p-p^{e}\right)+(1+\alpha) \theta \\
& \text { (1b) } y=\alpha(1-b)\left(p-p^{e}\right)+(1+\alpha) \theta \\
& \text { (1c) } y \equiv \int_{0}^{1} \mathrm{y}_{\mathrm{i}} \mathrm{di} \\
& \text { (1d) } b \equiv \int_{0}^{1} b_{i} d i \\
& \text { (1e) } \hat{y}=\theta \\
& \text { (1f) } m-p=y-\varepsilon \\
& \text { (1g) } p=p^{*}+s
\end{aligned}
$$

where $y_{i} \equiv \log$ of real output of firm i;

$b_{i} \equiv$ wage indexation parameter for firm $\mathrm{i}$;

$\mathrm{p} \equiv \log$ of the domestic price;

$\mathrm{y} \equiv \log$ of aggregate real output;

$\mathrm{b} \equiv$ aggregate wage indexation parameter;

$\theta \equiv$ random productivity shock, where $\theta \sim N\left(0, \sigma_{\theta}^{2}\right)$

$\hat{y} \equiv$ market-clearing, full-information output; 
$\mathrm{m} \equiv \log$ of the domestic money supply;

$\varepsilon \equiv$ random money demand shock, where $\varepsilon \sim N\left(0, \sigma_{\mathfrak{z}}^{2}\right)$

$\mathrm{p}^{*} \equiv \log$ of the foreign price;

$\mathrm{S} \equiv \log$ of the exchange rate, measured in terms of units of domestic currency per unit of foreign currency.

All parameters are nonnegative constants, and all intercepts have been suppressed as an analytical convenience.

Equation (1a) is the output supply function for an individual domestic firm, and Equation (1b) is the corresponding aggregate supply schedule for the domestic economy. If wage indexation is less than complete (i.e. if $b_{i}<1$ ), a positive price prediction error induces domestic firms to increase their output. Equations (1c) and (1d) define aggregate output and the aggregate degree of wage indexation, respectively. Equation (1e) gives the level of fullinformation output.

The money demand schedule is given in (1f) in which the money demand shock $(\varepsilon)$ is assumed to be uncorrelated with the productivity disturbance $(\theta)$. Because the economy is assumed to be a price taker in the world market, the law of one price is given in (1g).

Under the assumption of a flexible exchange rate, the following expressions can be derived from (1b), (1f), and (1g):

$$
\begin{gathered}
\mathrm{y}=\frac{\alpha(1-b)}{1+\alpha(1-b)}\left[\left(\mathrm{m}-\mathrm{m}^{\mathrm{e}}\right)+\varepsilon\right]+\frac{1+\alpha}{1+\alpha(1-b)} \theta \\
\mathrm{p}=\frac{1}{1+\alpha(1-b)}(\mathrm{m}+\varepsilon)+\frac{\alpha(1-b)}{1+\alpha(1-b)} \mathrm{m}^{\mathrm{e}}-\frac{1+\alpha}{1+\alpha(1-b)} \theta
\end{gathered}
$$




$$
\mathrm{s}=-\mathrm{p}^{*}+\frac{1}{1+\alpha(1-b)}(\mathrm{m}+\varepsilon)+\frac{\alpha(1-b)}{1+\alpha(1-b)} \mathrm{m}^{\mathrm{e}}-\frac{1+\alpha}{1+\alpha(1-b)} \theta
$$

where $m^{e}=p^{e}$ is the expected money supply. Under a managed or fixed exchange rate regime, $y, p$, and $m$ are endogenous variables. Under this exchange rate assumption, the following expressions can be derived:

$$
\begin{aligned}
& y=\alpha(1-b)\left(p^{*}+s-p^{e}\right)+(1+\alpha) \theta \\
& p=p^{*}+s \\
& m=[1+\alpha(1-b)]\left(p^{*}+s\right)-\alpha(1-b) p^{e}-\varepsilon+(1+\alpha) \theta
\end{aligned}
$$

\section{A Model of Interdependent Economies}

In interdependent economies, distinguishable goods are produced and consumed in each country. Domestic firms are uniformly distributed over the interval $i=0$ to $i=1$, while foreign firms are distributed uniformly over the interval $j=0$ to $j=1$. As in the SOE model, nominal wage contracts set the base wage equal to the expected value of the Walrasian, market-clearing wage, but domestic (foreign) wages are indexed to the domestic (foreign) consumer price index.

The structure of the two-country model is as follows:

(4c) $y=\alpha(1-b \Omega)\left(p-p^{e}\right)-\alpha(1-\Omega) b\left(p^{*}-p^{* e}\right)-\alpha(1-\Omega) b\left(s-s^{e}\right)+(1+\alpha) \theta$;

$$
y_{i}=\alpha\left(1-b_{i} \Omega\right)\left(p-p^{e}\right)-\alpha(1-\Omega) b_{i}\left(p^{*}-p^{* e}\right)-\alpha(1-\Omega) b_{i}\left(s-s^{e}\right)+(1+\alpha) \theta
$$$$
y_{j}^{*}=\alpha\left(1-b_{j}^{*} \Omega\right)\left(p^{*}-p^{*}\right)-\alpha(1-\Omega) b_{j}^{*}\left(p-p^{e}\right)+\alpha(1-\Omega) b_{j}^{*}\left(s-s^{e}\right)+(1+\alpha) \theta
$$

(4e) $y \equiv \int_{0}^{1} y, d i$

$$
y^{*} \equiv \int_{0}^{1} y_{j}^{*} d j
$$

$$
b \equiv \int_{0}^{1} b_{i} d i \quad b^{*} \equiv \int_{0}^{1} b_{j}^{*} d j
$$




$$
\begin{aligned}
& \text { (4g) } \hat{y}=\hat{y}^{*}=\theta \\
& \text { (4h) } \quad m-p=y-\varepsilon \\
& \text { (4i) } m^{*}-p^{*}=y^{*}-\varepsilon^{*} \\
& \text { (4j) } y=\delta\left(p^{*}+s-p\right)+\Omega y+(1-\Omega) y^{*}
\end{aligned}
$$

where foreign variables and policy parameters are denoted with an asterisk, where all variables are defined in Section 2 , and where

$$
\begin{aligned}
& \Omega \equiv \text { propensity to consume home goods, with } \Omega \geq 1 / 2 \\
& \varepsilon^{*} \equiv \text { random foreign money demand shock, where } \varepsilon^{*} \sim N\left(0, \sigma_{\varepsilon}^{2}\right) \text {. }
\end{aligned}
$$

Note that the productivity shock $(\theta)$, which is common to both countries, is assumed to be uncorrelated with $\varepsilon$ and $\varepsilon^{*}$. In addition, the domestic and foreign money demand shocks are assumed to be uncorrelated with each other. The derivation of the supply functions is outlined in Appendix A. Equation (4j) is the domestic income-expenditure equilibrium condition (the foreign analogue is deleted via Walras' law).

The solutions of the model depend on the assumption of which exchange rate regime prevails. Under the assumption of a flexible exchange rate, (4c), (4d), (4h), (4i), and (4j) can be used to obtain expressions for $y, y^{*}, p, p^{*}$, and $s$. The symmetric, semi-reduced-forms solutions for the nations' output levels are as follows:

$$
\begin{aligned}
& \mathrm{y}=\frac{A_{11}}{\Delta_{f}}\left[\left(\mathrm{~m}-\mathrm{m}^{\mathrm{e}}\right)+\varepsilon\right]+\frac{A_{12}}{\Delta_{f}}\left[\left(\mathrm{~m}^{*}-\mathrm{m}^{* \mathrm{e}}\right)+\varepsilon\right]+\frac{A_{13}}{\Delta_{f}}\left(\mathrm{~m}^{* \mathrm{e}}-\mathrm{m}^{\mathrm{e}}\right)+\frac{A_{14}}{\Delta_{f}} \theta \\
& \mathrm{y}^{*}=\frac{A_{21}}{\Delta_{f}}\left[\left(\mathrm{~m}-\mathrm{m}^{\mathrm{e}}\right)+\varepsilon\right]+\frac{A_{22}}{\Delta_{f}}\left[\left(\mathrm{~m}^{*}-\mathrm{m}^{* \mathrm{e}}\right)+\varepsilon\right]+\frac{A_{23}}{\Delta_{f}}\left(\mathrm{~m}^{* \mathrm{e}}-\mathrm{m}^{\mathrm{e}}\right)+\frac{A_{24}}{\Delta_{f}} \theta
\end{aligned}
$$

where the expressions for $\Delta_{f}$ and the "A" coefficients are given in Appendix B. 
The domestic consumer price index is given by $\Psi=(1-\Omega) p+\Omega\left(p^{*}+s\right)$, while the foreign CPI is equal to $\Psi^{*}=(1-\Omega) p^{*}+\Omega(p-s)$. Assuming that (logs of $)$ the price levels and exchange rate in the previous period are equal to zero, the symmetric, semi-reduced-form solutions for the ex ante values of the CPI inflation rates are

$$
\begin{aligned}
\Psi & =\frac{B_{11}}{\Delta_{f}}\left[\left(\mathrm{~m}-\mathrm{m}^{\mathrm{e}}\right)+\varepsilon\right]-\frac{B_{12}}{\Delta_{f}}\left[\left(\mathrm{~m}^{*}-\mathrm{m}^{* \mathrm{e}}\right)+\varepsilon\right]-\frac{B_{13}}{\Delta_{f}} \mathrm{~m}^{\mathrm{e}}+\frac{B_{14}}{\Delta_{f}} \mathrm{~m}^{{ }^{\mathrm{e}}}-\frac{B_{15}}{\Delta_{f}} \theta \\
\Psi^{*} & =-\frac{B_{21}}{\Delta_{f}}\left[\left(\mathrm{~m}-\mathrm{m}^{\mathrm{e}}\right)+\varepsilon\right]+\frac{B_{22}}{\Delta_{f}}\left[\left(\mathrm{~m}^{*}-\mathrm{m}^{* \mathrm{e}}\right)+\varepsilon\right]+\frac{B_{23}}{\Delta_{f}} \mathrm{~m}^{\mathrm{e}}-\frac{B_{24}}{\Delta_{f}} \mathrm{~m}^{* \mathrm{e}}-\frac{B_{25}}{\Delta_{f}} \theta
\end{aligned}
$$

Under the assumption of a managed exchange rate, the five equations referenced above can be solved for $y, y^{*}, p, p^{*}$, and $m^{*}$. We follow Giavazzi and Giovannini (1989) by specifying that a managed exchange rate regime is one in which the domestic monetary authority determines the underlying inflation rate for the two economies while the foreign monetary authority chooses the bilateral exchange rate. ${ }^{4}$ The asymmetric, semi-reduced-form solutions for the nations' output and price levels are given as

$$
\begin{aligned}
& \mathrm{y}=\frac{A_{31}}{\Delta_{m}}\left[\left(\mathrm{~m}-\mathrm{m}^{\mathrm{e}}\right)+\varepsilon\right]-\frac{A_{32}}{\Delta_{m}}\left(\mathrm{~s}-\mathrm{s}^{\mathrm{e}}\right)+\frac{A_{33}}{\Delta_{m}} \theta \\
& \mathrm{y}^{*}=\frac{A_{41}}{\Delta_{m}}\left[\left(\mathrm{~m}-\mathrm{m}^{\mathrm{e}}\right)+\varepsilon\right]-\frac{A_{42}}{\Delta_{m}}\left(\mathrm{~s}-\mathrm{s}^{\mathrm{e}}\right)+\frac{A_{43}}{\Delta_{m}} \theta
\end{aligned}
$$

${ }^{4}$ There are two ways in which we could consider a fixed exchange rate regime. Under one methodology, the domestic monetary authority would choose the common inflation rate while the foreign monetary authority would commit to change its money supply to keep the bilateral exchange rate fixed. In the other method, both monetary authorities could commit to a coordinated detemination of the exchange rate. However, we assume throughout the paper that monetary authorities are unable to commit credibly. Thus, we eschew consideration of a fixed exchange rate regime. 


$$
\begin{gathered}
\mathrm{p}=\mathrm{m}^{\mathrm{e}}+\frac{A_{51}}{\Delta_{m}}\left[\left(\mathrm{~m}-\mathrm{m}^{\mathrm{e}}\right)+\varepsilon\right]+\frac{A_{52}}{\Delta_{m}}\left(\mathrm{~s}-\mathrm{s}^{\mathrm{e}}\right)-\frac{A_{53}}{\Delta_{m}} \theta \\
\mathrm{p}^{*}=\mathrm{m}^{\mathrm{e}}-\mathrm{s}^{\mathrm{e}}+\frac{A_{61}}{\Delta_{m}}\left[\left(\mathrm{~m}-\mathrm{m}^{\mathrm{e}}\right)+\varepsilon\right]-\frac{A_{62}}{\Delta_{m}}\left(\mathrm{~s}-\mathrm{s}^{\mathrm{e}}\right)-\frac{A_{63}}{\Delta_{m}} \theta
\end{gathered}
$$

Note that the foreign money demand disturbance $\left(\varepsilon^{*}\right)$ has no effect on output or inflation in either country. In order to realize a desired value of $s$, the foreign monetary authority must vary the foreign money supply to offset exactly the effect of the foreign money demand shock.

Equations (6c) and (6d) can be used to give expressions for the nation's CPI inflation rates:

$$
\begin{gathered}
\Psi=\mathrm{m}^{\mathrm{e}}+\frac{B_{31}}{\Delta_{m}}\left[\left(\mathrm{~m}-\mathrm{m}^{\mathrm{e}}\right)+\varepsilon\right]+\frac{B_{32}}{\Delta_{m}}\left(\mathrm{~s}-\mathrm{s}^{\mathrm{e}}\right)-\frac{B_{33}}{\Delta_{m}} \theta \\
\Psi^{*}=\mathrm{m}^{\mathrm{e}}-\mathrm{s}^{\mathrm{e}}+\frac{B_{41}}{\Delta_{m}}\left[\left(\mathrm{~m}-\mathrm{m}^{\mathrm{e}}\right)+\varepsilon\right]-\frac{B_{42}}{\Delta_{m}}\left(\mathrm{~s}-\mathrm{s}^{\mathrm{e}}\right)-\frac{B_{43}}{\Delta_{m}} \theta
\end{gathered}
$$

\section{Optimal Monetary and Exchange Rate Policies}

Regardless of the size of the economy, the nature of the game between wage setters and monetary authorities is the same. Atomistic wage setters make base wage and indexation choices before stochastic disturbances are realized, but in anticipation of the monetary authorities' policy choices. We assume that monetary authorities make their policy choices before the realization of stochastic shocks. ${ }^{5}$

${ }^{5}$ This timing assumption follows Barro and Gordon (1983), Devereux (1987), and Waller and VanHoose (1992), among others. For examples of games in which disturbances are fully observable by monetary authorities, see Canzoneri (1985), Rogoff (1985), and Rasmussen (1993). VanHoose and Waller (1991) analyze how indexation choices in a closed economy are affected by the authorities' ability to observe stochastic disturbances before or after monetary policy decisions are made. 


\subsection{Small Open Economy}

In a SOE, the domestic monetary authorities seek to minimize the loss function

$$
L_{A}=(1 / 2) E\left[(y-\tilde{y})^{2}+\beta \Pi^{2}\right]
$$

where $\mathrm{E}$ is the expectations operator, where $\tilde{y}$ is the output target with $\tilde{y}=\hat{y}+K$, and where $\Pi=p-p_{-I}=p$. The parameter $K$, a positive constant, is an output distortion, perhaps arising from distortionary taxation, that the monetary authorities seek to offset. $\beta$ is the relative weight that the domestic monetary authorities place on achieving the inflation objective.

Under a flexible exchange rate, the domestic monetary authorities choose $m$ to minimize (7), taking $m^{e}$ and $s^{e}$ as given, ex ante. Substituting (3a) and (3b) into (7), differentiating with respect to $m$, imposing $m=m^{e}$ and $s=s^{e}$ ex post, and rearranging yields

$$
\tilde{m}=\frac{\alpha(1-b)}{\beta} K
$$

as the authorities' optimal policy choice. ${ }^{6}$ Using similar methodology, an identical solution is found for $s$ under a managed exchange rate regime.

The solution for $\tilde{m}$ (and for $\tilde{s}$ ) implies that the trend inflation rate is equal to $\Pi=\tilde{m}>0$, so that there is an inflation bias in monetary policy. However, note that $\tilde{m}=0$ if $b=1$. Hence, as noted by Devereux (1987) and others, greater indexation worsens the terms of the output-inflation tradeoff. As shown below, however, complete indexation generally is not optimal because there are supply-side disturbances that cause actual output to vary from full-information output.

\footnotetext{
${ }^{6}$ Under the assumption that the domestic monetary authority can commit credibility, $m=m^{e}$, $e x$ ante. In this case, $m=0$ and thus, there is no inflation bias. This replicates the famous result found in Barro and Gordon (1983).
} 


\subsection{Interdependent Economies}

Under a managed exchange rate regime, the domestic monetary authority chooses $m$ to minimize

$$
L_{A}=(1 / 2) E\left[(y-\tilde{y})^{2}+\beta \Psi^{2}\right]
$$

while the foreign monetary authority chooses $s$ to minimize

$$
L_{A}^{*}=(1 / 2) E\left[\left(y^{*}-\tilde{y}\right)^{2}+\beta(\Psi)^{2}\right]
$$

Substituting expressions from (6) into (9a) and (9b), differentiating (9a) with respect to $m$ and (9b) with respect to $s$, imposing $m=m^{e}$ and $s=s^{e}$ ex post, and solving the resulting expressions simultaneously yields

$$
\begin{gathered}
\hat{m}=\mathrm{m}^{\mathrm{e}}=\mathrm{C}_{11} \mathrm{~K} \\
\hat{s}=\mathrm{s}^{\mathrm{e}}=\hat{m}-\mathrm{C}_{12} \mathrm{~K}=\left(\mathrm{C}_{11}-\mathrm{C}_{12}\right) \mathrm{K}
\end{gathered}
$$

where the "C" coefficients are given in Appendix B. It can be shown that if $b=b^{*}=1$, then $m=s=0$. Consistent with the SOE case, complete wage indexation eliminates the inflationary bias of monetary policy.

Under a flexible exchange rate regime, the domestic monetary authority chooses $m$ to minimize (9a) while the foreign monetary authority chooses $m^{*}$ to minimize (9b). Optimal money supply choices are given as 
(11a)

$$
\begin{aligned}
& m=\left(\frac{A_{11} D_{22}+A_{22} D_{12}}{D_{12} D_{21}-D_{11} D_{22}}\right) \Delta_{f} K \\
& m^{*}=\left(\frac{A_{22} D_{11}+A_{11} D_{21}}{D_{12} D_{21}-D_{11} D_{22}}\right) \Delta_{f} K
\end{aligned}
$$

where the " $D$ " coefficients are given in Appendix B. Examination of $A_{11}$ and $A_{22}$ in Appendix B reveals that $m=m^{*}=0$ when $b=b^{*}=1$.

\section{Equilibrium Indexation Choices}

Regardless of country size or exchange rate regime, we assume that wage setters are atomistic. ${ }^{7}$ Consequently, they seek to minimize firm-specific losses,

$$
\begin{gathered}
L_{w_{i}}=(1 / 2) E\left[\left(y_{i}-\hat{y}\right)^{2}+\beta_{W} \Psi^{2}\right] \\
L_{w_{j}}^{*}=(1 / 2) E\left[\left(y_{j}^{*}-\hat{y}^{*}\right)^{2}+\beta_{w^{\prime}}\left(\Psi^{*}\right)^{2}\right]
\end{gathered}
$$

where wage setters' inflation weight $\beta_{\mathrm{w}}$ may or may not equal $\beta$. In addition, the firmspecific loss functions differ from the authorities' loss functions in that wage setters care only about departures of actual output from full-information output. ${ }^{8}$ Recall that the monetary authorities also desire to offset the output distortion $\mathrm{K}$.

Because they are "small", individual wage setters exert no effects on the aggregate degrees of indexation, $b$ and $b^{*}$. As a result, the model is solved with $\frac{\partial b}{\partial b_{i}}=0$ and $\frac{\partial b^{*}}{\partial b_{j}}=0$,

${ }^{7}$ Due to space limitations, and to keep the analysis as simple as possible, we eschew considerations of centralized wage indexation. See Waller and VanHoose (1992) for a discussion of the differences between atomistic and centralized wage indexation in a closed economy.

${ }^{8}$ Aizenman and Frenkel (1985) show how this type of objective function is consistent with the assumption of utility-maximizing consumers. 
so that $\frac{\partial \Psi}{\partial b_{i}}=\left(\frac{\partial \Psi}{\partial b}\right)\left(\frac{\partial b}{\partial b_{i}}\right)=0$ and $\frac{\partial \Psi^{*}}{\partial b_{j}}=\left(\frac{\partial \Psi^{*}}{\partial b^{*}}\right)\left(\frac{\partial b^{*}}{\partial b_{j}}\right)=0$ Thus, individual wage setters ignore

the effect that their indexation decisions, taken in the aggregate, have on the inflation rate.

\subsection{Equilibrium Wage Indexation in a Smail Open Economy}

To find the equilibrium indexation choice under a flexible exchange rate in a SOE, we substitute the equilibrium money supply $[(8)]$ into the price level solution $[(3 b)]$, and the result into the firm supply function [(1a)]. We then substitute the resulting expressions for $p$ and $y$ into [(12a)] and minimize with respect to $b_{i}$. Imposing the symmetric Nash equilibrium conditions that $b_{i}=b$ for all $i$ yields the equilibrium wage indexation choice as

$$
b=\frac{\sigma_{\varepsilon}^{2}}{\sigma_{\varepsilon}^{2}+(1+\alpha) \sigma_{\theta}^{2}}
$$

which is the standard Gray (1976) closed economy result. Similar methodology yields an identical expression for the managed exchange rate regime. ${ }^{9}$ Because there is no economic interdependence in a SOE, wage setters choose the same degree of wage indexation as they would in a closed economy.

\subsection{Equilibrium Wage Indexation in Interdependent Economies Under a Managed Exchange Rate}

To find equilibrium indexation choices in a managed exchange rate regime, we substitute the equilibrium choices of $m[(10 a)]$ and $s[(10 b)]$ into semi-reduced form solutions

\footnotetext{
${ }^{9}$ Our result for a managed exchange rate differs from Flood and Marion (1982), who find that complete indexation is optimal for a SOE under a fixed exchange rate, because we assume a common productivity disturbance. Flood and Marion assume that the productivity disturbance in the SOE is different from that in the rest of the world. In an environment in which the policymaker observes stochastic disturbances, Rasmussen (1993) finds that the optimal degree of wage indexation is less than unity if the variance of supply shocks is large relative to the incentive to create surprise inflation.
} 
for $p$ and $p^{*}$. We then substitute the results into the firm supply functions [(1a) and (1b)] and the CPI inflation rates [(6e) and (6f)]. Minimizing (12a) with respect to $b_{i}$, (12b) with respect to $b_{i}$, and imposing the symmetric Nash equilibrium conditions that $b_{i}=b$ and $b_{j}{ }^{*}=b^{*}$ for all $\mathrm{i}$ and $\mathrm{j}$ yields aggregate reaction functions $b\left(b^{*}\right)$ and $b^{*}(b)$ under a managed exchange rate:

$$
\begin{aligned}
& b\left(b^{*}\right)=\frac{\phi\left(b^{*}\right) \sigma_{\varepsilon}^{2}}{\Lambda\left(b^{*}\right) \sigma_{\varepsilon}^{2}+\mathrm{X}\left(b^{*}\right) \sigma_{\theta}^{2}} \\
& b^{*}(b)=\frac{\phi^{*}(b) \sigma_{\varepsilon}^{2}+b \mathrm{Y}^{*}(b) \sigma_{\theta}^{2}}{\Lambda^{*}(b) \sigma_{\varepsilon}^{2}+\mathrm{X}^{*}(b) \sigma_{\theta}^{2}}
\end{aligned}
$$

where $\Phi\left(b^{*}\right)=\delta+\alpha(1-\Omega)\left(1-b^{*} \Omega\right)$,

$$
\begin{aligned}
& \Lambda\left(b^{*}\right)=\delta+\alpha(1-\Omega)\left[\Omega+b^{*}(1-2 \Omega)\right] \\
& \mathrm{X}\left(b^{*}\right)=(1+\alpha)\left\{\delta+\alpha(1-\Omega)\left[1+b^{*}(1-2 \Omega)\right]\right\} \\
& \Phi^{*}(b)=\delta+\alpha(1-\Omega)(1-b \Omega) \\
& \mathrm{Y}^{*}(b)=\alpha(1+\alpha)(\Omega-1+\delta) \\
& \Lambda^{*}(b)=\delta+\alpha(1-\Omega)[\Omega+b(1-2 \Omega)] \\
& \mathrm{X}^{*}(b)=(1+\alpha)\{\delta(1+\alpha)+\alpha b(1-\Omega)(1-2 \Omega)\}
\end{aligned}
$$

Although the nonlinearities inherent in equations (14) imply potential for multiple indexation solutions, only one pair of solutions exist that are real-valued, nonnegative, and less than or equal to 1 . This pair is 


$$
b=b^{*}=\frac{\sigma_{\varepsilon}^{2}}{\sigma_{\varepsilon}^{2}+(1+\alpha) \sigma_{\theta}^{2}}
$$

When authorities implement monetary policy prior to the realization of stochastic shocks, wage setters in interdependent economies that are tied together with a managed exchange rate choose the same degree of wage indexation as wage setters in a $\mathrm{SOE}^{10}$.

To understand the intuition behind this result, note from (10b) that the exchange rate selected by the foreign monetary authority is invariant to stochastic disturbances. ${ }^{11}$ In addition, it can be shown from (6c), (6d), and the expressions in Appendix B that $p=p^{*}$ when $b=b^{*}$. In equilibrium, when domestic and foreign wage setters choose the same degree of wage indexation, the effects of the stochastic disturbances on the foreign (domestic) economy do not spill over to the domestic (foreign) economy. Thus, wage setters in each economy choose the same degree of indexation that they would in a SOE (or in a closed economy).

\subsection{Equilibrium Wage Indexation in Interdependent Economies Under a Flexible Exchange Rate}

Using similar methodology as above, optimal indexation choices under a flexible exchange rate regime can be derived as

${ }^{10}$ This result depends on the assumption that both countries experience common productivity shocks. If supply shocks are idiosyncratic, wage setters in the domestic economy will choose a degree of wage indexation that differs from the degree chosen in the foreign economy or in a SOE.

"Under the informational assumptions that we make, the foreign monetary authority does not observe the stochastic disturbances directly. However, ex post, the authorities observe changes in the exchange rate that are caused by stochastic disturbances, and change the foreign money by an appropriate amount to keep the exchange rate at the optimal level given in (10b). 


$$
b^{\prime}\left(b^{\prime}\right)=\frac{\rho\left(b^{n}\right) \sigma_{\varepsilon}^{2}}{\rho\left(b^{n}\right) \sigma_{\varepsilon}^{2}+\xi\left(b^{n}\right) \sigma_{\varepsilon^{*}}^{2}+v\left(b^{n}\right) \sigma_{\theta}^{2}}
$$

$$
b^{*}(b)=\frac{\rho^{*}(b) \sigma_{\varepsilon^{\cdot}}^{2}}{\rho^{*}(b) \sigma_{\varepsilon^{*}}^{2}+\xi^{*}(b) \sigma_{\varepsilon}^{2}+v^{*}(b) \sigma_{\theta}^{2}}
$$

where $\rho\left(b^{*}\right)=\left\{\alpha b^{*}(1-\Omega)^{2}+\delta\left[1+\alpha\left(1-b^{*}\right)\right]\right\}\left\{\alpha(1-\Omega)^{2}\left[1+b^{*}+\alpha\left(1-b^{*}\right)\right]+\delta\left[1+\alpha\left(1-b^{*}\right)\right]\right\}$,

$$
\begin{aligned}
& \xi\left(b^{*}\right)=\alpha^{2}(1+\alpha)(1-\Omega)^{4}\left(1-b^{*}\right)^{2} \\
& v\left(b^{*}\right)=(1+\alpha)\left\{2 \alpha b^{*}(1-\Omega)^{2}+\delta\left[1+\alpha\left(1-b^{*}\right)\right]\right\}^{2}, \\
& \rho^{*}(b)=\left\{\alpha b(1-\Omega)^{2}+\delta[1+\alpha(1-b)]\right\}\left\{\alpha(1-\Omega)^{2}[1+b+\alpha(1-b)]+\delta[1+\alpha(1-b)]\right\} \\
& \xi^{*}(b)=\alpha^{2}(1+\alpha)(1-\Omega)^{4}(1-b)^{2} \\
& v^{*}(b)=(1+\alpha)\left\{2 \alpha b(1-\Omega)^{2}+\delta[1+\alpha(1-b)]\right\}^{2}
\end{aligned}
$$

Note that the forms of these reaction functions are symmetric. This does not mean that the implied solutions for $b$ and $b^{*}$ necessarily are identical, however, because the country-specific demand variances $\sigma_{\varepsilon}^{2}$ and $\sigma_{\varepsilon}^{2}$. generally will not be equal.

Note from equations (16a) and (16b) that if $\sigma_{\mathrm{e}^{*}}^{2}=\sigma_{\theta}^{2}=0$, then $b=1$ and $b^{*}=0$. If all the disturbances are in domestic demand, then it is optimal for domestic wage setters to index wages completely. Thus, domestic output will remain unchanged in the face of domestic demand shocks, but the domestic price and the exchange rate will fluctuate. As can be seen in equation (4d), it is optimal for foreign wage setters to choose $b^{*}=0$ to offset the effects of changes in the domestic price and the exchange rate that act as supply disturbances from the standpoint of the foreign country. Analogous reasoning applies for why $b=0$ and $b^{*}=1$ when $\sigma_{\varepsilon}^{2}=\sigma_{\theta}^{2}=0$. Note that if $\sigma_{\varepsilon}^{2}=\sigma_{\varepsilon^{*}}^{2}=0$, then $b=b^{*}=0$. 
Considerable algebraic manipulations verify that the general aggregate indexation reaction functions in (16) may slope upward or downward and that their slopes are not necessarily monotonic over the ranges $0<b, b^{*}<1$. The full expressions for these slopes are extremely lengthy and depend on all the parameters and structural variances of the model. They also are not readily amenable to further algebraic manipulation.

To explore further what factors influence the nature of the cross-country strategic interactions in indexation choices, we conduct the following experiment. We fix $b^{*}$ at its two extreme values, 0 and 1 , and compute the values of $b$, for each extreme value of $b^{*}$, that are implied by (16a). We then compare these solutions for $b$ to infer what factors govern the direction of the responss of domestic indexation to an exogenous change in foreign indexation.

Comparing the solutions for $b$, we find that (for nonzero values of $\sigma_{\varepsilon}^{2}$ )

$$
\left.b\right|_{b^{\circ}=1}>\left.b\right|_{b^{\circ}=0} \text { if } \frac{\sigma_{\varepsilon^{*}}^{2}}{\sigma_{\theta}^{2}}>\frac{2 \delta(1+\alpha)^{2}}{\alpha(1-\Omega)^{2}} \text {, }
$$

$$
\left.b\right|_{t^{\circ}=1}<\left.b\right|_{t^{\circ}=0} \text { if } \frac{\sigma_{\varepsilon^{*}}^{2}}{\sigma_{\theta}^{2}}<\frac{2 \delta(1+\alpha)^{2}}{\alpha(1-\Omega)^{2}} \text {. }
$$

Thus, if the variability of foreign money demand shocks relative to supply shocks exceeds some threshold (given by the righthand side of the inequality), then the optimal degree of domestic wage indexation declines (rises) as the foreign wage indexation coefficient falls (rises) from 1 to 0 (from 0 to 1 ). In this case, the wage indexation choices are strategic complements. If, however, the variance ratio is less than the threshold, then indexation 
choices are strategic substitutes. That is, the aggregate indexation choice in one nation is negatively related to the aggregate indexation choice in the other nation.

For a given ratio of $\sigma_{e}^{2}$ to $\sigma_{\theta}^{2}$, the likelihood that wage indexation choices will be strategic complements rises as the economies become more interdependent (i.e. as $\delta$ and/or $\Omega$ decline). For any given ratio of $\sigma_{\varepsilon}^{2}$ to $\sigma_{\theta}^{2}$, the variability of the real exchange rate rises with the degree of interdependence. By rewriting (4c) as

$$
y=\alpha\left(p-p^{e}\right)+\alpha b \Omega\left(z-z^{e}\right)-\alpha b\left[\left(p^{*}-p^{e}\right)+\left(s-s^{e}\right)\right]+(1+\alpha) \theta
$$

where $\mathrm{Z} \equiv\left(p^{*}+s-p\right) \equiv$ the real exchange rate, it is apparent that changes in the real exchange rate act as supply shocks. ${ }^{12}$ Ceteris paribus, domestic wage setters would choose a low value of $b$ to minimize the effects of these induced supply shocks. However, an exogenous rise in $b^{*}$ attenuates the variability of the real exchange rate and allows domestic wage setters to choose a higher value of $b$ to minimize the effects of domestic money demand shocks. In this case, wage indexation choices are strategic complements.

How does interdependence affect equilibrium indexation choices relative to the optimal degree of indexation in a SOE? Comparing (16a) to (13), it can be shown that, in general, wage setters in interdependent may choose either higher or lower degrees of wage indexation than wage setters in small open economies. However, for given values of $b^{*}$ the likelihood that domestic wage setters in an interdependent economy will choose lower values of $b$ than

\footnotetext{
${ }^{12}$ The domestic consumer price index is given by $q=(1-\Omega) p+\Omega(p+s)=p+\Omega z$. Because domestic wage setters index to the domestic CPI, a change in the real exchange rate changes the real wage and thus, acts as a supply shock. By similar reasoning, it can be shown that foreign output is affected by changes in the real exchange rate.
} 
they would in a SOE rises as $\delta$ and/or $\Omega$ decline (i.e. as the economies become more interdependent), as $\sigma_{\varepsilon}^{2}$ rises relative to $\sigma_{\theta}^{2}$, and as $\alpha$ declines.

The intuition for why wage setters in interdependent economies are more likely to choose lower wage indexation coefficients as $\delta$ and/or $\Omega$ decline is straightforward. Recall that for any given ratio of $\sigma_{\varepsilon}^{2}$. to $\sigma_{\theta}^{2}$, the variability of the real exchange rate rises as $\delta$ and/or $\Omega$ decline. Thus, wage setters in an interdependent economy will choose lower degrees of wage indexation than they would in a SOE to minimize the effects of real exchange rate changes that act as induced supply shocks.

Similarly, domestic money demand shocks affect domestic and foreign variables in interdependent economies. In a SOE, domestic demand shocks affect only domestic variables. When $\sigma_{\theta}^{2}=0$, wage setters in either a SOE or an interdependent economy will choose $b=0$ to minimize the effect of the supply shocks. However, as $\sigma_{\varepsilon}^{2}$ rises relative to $\sigma_{\theta}^{2}$, wage setters in interdependent economies will choose lower degrees of wage indexation (relative to the choice in a SOE) to minimize the effects of changes in the foreign price and the exchange rate that change the real wage, and thereby act as domestic supply shocks.

Finally, as $\alpha$ declines in value, the supply curve becomes steeper. For a given supply shock, output is displaced more as the supply curve steepens. Wage setters in interdependent economies face not only productivity shocks $(\theta)$ but also changes in the foreign price and exchange rate that act as domestic supply shocks. Wage setters in a SOE face only the former. Thus, as the supply curve steepens, wage setters in interdependent economies will choose lower degrees of wage indexation (relative to a SOE) to minimize the affects of supply shocks induced by changes in $p^{*}$ and $s$. 
In sum, changes in the foreign price and exchange rate that affect the real wage and act as supply shocks in interdependent economies are absent in a SOE. Further, these induced supply shocks in an interdependent economy become more pronounced as $\delta, \Omega$, and $\alpha$ decline and as $\sigma_{\varepsilon}^{2}$ rises relative to $\sigma_{\theta}^{2}$, and make it more likely that wage setters in interdependent economies will choose lower degrees of wage indexation relative to their counterparts in a SOE.

In principle, simultaneous solution of the wage indexation reaction functions [(16a) and (16b)] would yield equilibrium wage indexation choices. However, closed-form solutions for $b$ and $b^{*}$ are not readily obtainable from the general expressions in (16), and so we conducted numerical simulations for the special case in which the countries experience common variances of demand disturbances $\left(\sigma_{\varepsilon}^{2}=\sigma_{\varepsilon}^{2}\right)$, so that $b=b^{*}$ in equilibrium. Even then, multiple solutions existed, although we obtained only one economically feasible solution that was real-valued, nonnegative, and less than or equal to 1 . The simulation results are presented in Tables 1, 2, and 3 .

Each cell in the following tables shows the equilibrium degree of wage indexation in the domestic and the foreign economies. The solutions in the cells in the right-hand column of each table correspond to the SOE outcomes which arise for the limiting case of $\delta \rightarrow \infty$. Similarly, the solutions in the bottom row of each table (where $\Omega=1$ ) correspond to closed economy solutions which, as discussed above, are equivalent to SOE outcomes. Entries in the upper left part of each table (low values of $\delta$ and $\Omega$ ) correspond to wage indexation choices in highly interdependent economies.

The results in Table 1 confirm the general result discussed above that interdependence raises the likelihood that wage setters will choose lower indexation coefficients than they 
would in a SOE. ${ }^{13}$ The entries in the upper left part of Table 1 are smaller than those in the right-hand column or in the bottom row. Thus, wage indexation in highly interdependent economies is lower than in a SOE. For example, when $\delta=0.001$ and $\Omega=0.5$, wage setters in interdependent economies will choose a wage indexation coefficient of 0.22 compared with their counterparts in a SOE who choose a coefficient of 0.33. As the economies become less interdependent (as $\delta$ and $\Omega$ rise), the equilibrium degree of wage indexation rises. Note that for some parameter values, wage setters in interdependent economies choose higher indexation coefficients than wage setters in small open economies.

\begin{tabular}{|c|c|c|c|c|c|c|c|c|}
\hline & & \multicolumn{7}{|c|}{$\begin{array}{l}\text { Table 1: Wage Indexation Choices }\left(\boldsymbol{b} \text { and } \boldsymbol{b}^{*}\right) \\
\qquad\left(\alpha=1, \sigma_{\varepsilon}^{2}=\sigma_{\varepsilon^{*}}^{2}=\sigma_{\theta}^{2}\right)\end{array}$} \\
\hline & & \multicolumn{7}{|c|}{$\delta$} \\
\hline & & 0.001 & 0.01 & 0.1 & 1 & 10 & 100 & $\infty$ \\
\hline \multirow{4}{*}{$\Omega$} & 0.5 & 0.22 & 0.29 & 0.37 & 0.36 & 0.34 & 0.33 & 0.33 \\
\hline & 0.7 & 0.24 & 0.33 & 0.38 & 0.34 & 0.34 & 0.33 & 0.33 \\
\hline & 0.9 & 0.32 & 0.38 & 0.35 & 0.34 & 0.33 & 0.33 & 0.33 \\
\hline & 1.0 & 0.33 & 0.33 & 0.33 & 0.33 & 0.33 & 0.33 & 0.33 \\
\hline
\end{tabular}

Table 2 shows the effect that a rise in $\sigma_{\varepsilon}^{2}$ relative to $\sigma_{\theta}^{2}$ has on the equilibrium degree of wage indexation. (For the simulation results reported in Table 1 , we set $\sigma_{\varepsilon}^{2}=\sigma_{\varepsilon^{-}}^{2}=\sigma_{\theta}^{2}$. In

${ }^{13}$ Our choice of $\alpha=1$ is supported by results in Abramowicz and Woglom (1995) that suggest that slopes of aggregate supply functions in the United States and other nations are close to 1 . Our choice of $\sigma_{\varepsilon}^{2}=\sigma_{\varepsilon^{\cdot}}^{2}=\sigma_{\theta}^{2}$ serves strictly as a benchmark. 
Table 2, we chose $\sigma_{\varepsilon}^{2}=\sigma_{z^{\circ}}^{2}=4\left(\sigma_{\theta}^{2}\right)$.) The theoretical result discussed above suggests that a rise in $\sigma_{\varepsilon}^{2}$ relative to $\sigma_{\theta}^{2}$ should increase the likelihood that wage setters in interdependent economies will choose lower degrees of wage indexation than they would in a SOE. This prediction is confirmed by the results in Table 2 which displays no cases in which wage setters in interdependent economies choose a higher degree of indexation than wage setters in a SOE. Referring back to Table 1 , it is apparent that there are many parameter values for which indexation choices in interdependent economies are higher than in a SOE.

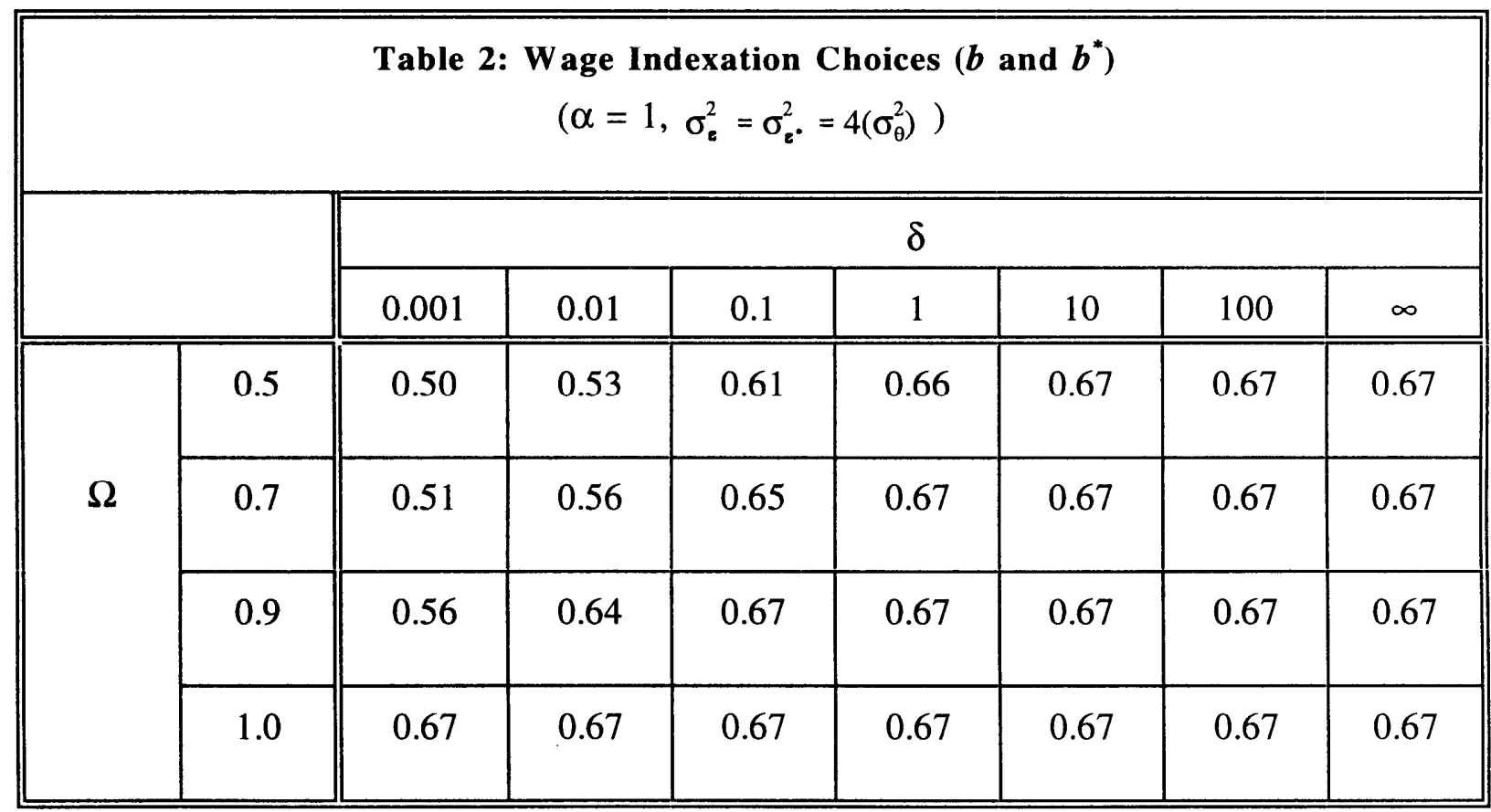

In Table 3, we repeat the simulation reported in Table 1 except that we reduce $\alpha$ from 1 to 0.1 to ascertain what effects a steeper supply curve has on equilibrium wage indexation choices. In contrast to Table 1 where there were some cases in which wage setters in interdependent economies chose a higher degree of indexation than their counterparts in a 
SOE, there are no such reported cases in Table $3 .^{14}$ This supports the general result discussed previously.

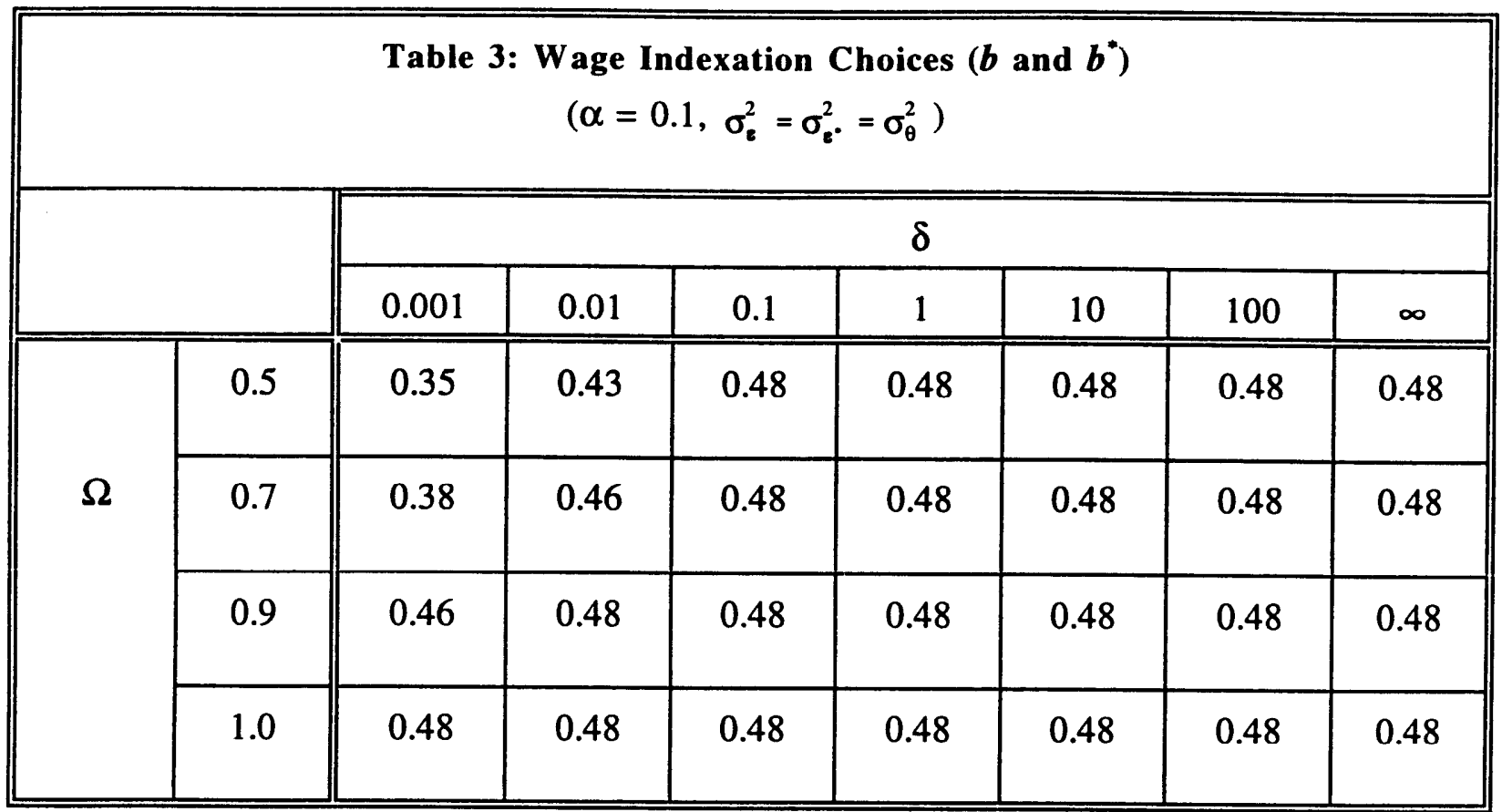

\section{Conclusion}

This paper has examined how economic interdependence can affect the equilibrium degrees of wage indexation chosen by wage setters. Whereas only one equilibrium indexation solution exists in a small open economy, we found the potential for multiple indexation solutions in interdependent economies. However, only one of these solutions is economically feasible. Under a managed exchange rate regime in which monetary authorities do not observe stochastic disturbances before implementing monetary policy, we have shown that

${ }^{14}$ The reason that there are very few entries in Table 3 that differ from the choice made in a SOE is due to the very low value of $\alpha$. As $\alpha \rightarrow 0$, the interdependent economy result converges to the SOE result. This is because as $\alpha \rightarrow 0$, the supply curve approaches a vertical line. In this case, only productivity shocks, and not induced supply shocks caused by changes in $p^{*}$ and $s$, can shift the supply curve and displace output. 
atomistic wage setters choose a degree of wage indexation that is identical to that chosen in a small open economy. Under a flexible exchange rate regime, the optimal degree of wage indexation may be in general either higher or lower than optimal indexation in small open economies. However, the likelihood that indexation choices in interdependent economies will be lower than in small open economies rises as the degree of interdependence rises, as the variance of money demand shocks rises relative to supply shocks, and as aggregate supply curves steepen.

We also have analyzed the interaction between wage indexation choices in interdependent economies and have shown that wage indexation choices in general may be either strategic complements or strategic substitutes. However, the likelihood that wage indexation choices will be strategic complements rises as the degree of interdependence rises and as the variance of foreign money demand shocks rises relative to supply shocks.

It is important to emphasize that we have obtained these results in a setting in which wage indexation is atomistic: Wage setters determine their firm-level indexation choices under the assumption that those individual choices cannot influence the inflation rate and, consequently, the behavior of policymakers. Although this assumption is consistent with the bulk of the literature on wage indexation, Bruno and Sachs (1985) and Calmfors and Driffill (1988) have documented significant contrasts among wage-setting institutions throughout Europe and elsewhere in the world, and recent work by Waller and VanHoose (1992), MilesiFerretti (1994), Cubitt (1992), Akhand (1992), and Jensen (1993) has shown how centralized wage setting can influence the policy choices of discretionary monetary authorities in closed economies. Our initial efforts to examine centralized wage setting in the above two-country framework indicate that centralization expands the scope for interdependence spillovers and 
strategic interactions, thereby increasing the potential for multiple indexation solutions. This topic, however, lies beyond the bounds of the present, more limited study. 


\section{APPENDIX A}

The supply side of the model is given by the following equations:
(A1) $y_{i}=a_{0} l_{i}+\theta$
$y_{j}^{*}=a_{0} l_{j}^{*}+\theta$,
$0<a_{0}<1$
(A2) $l_{i}^{d}=-a_{l}\left(w_{i}-p-\theta\right)$,
$l_{j}^{* d}=-a_{I}\left(w_{j}^{*}-p^{*}-\theta\right)$,
$a_{1} \equiv 1 /\left(1-a_{0}\right)$
(A3) $l_{i}^{s}=\Gamma\left(w_{i}-q\right)$,
$l_{j}^{*}=\Gamma\left(w_{j}^{*}-q^{*}\right)$
(A4)
$q=\Omega p+(1-\Omega)\left(p^{*}+s\right)$
$q^{*}=\Omega p^{*}+(1-\Omega)(p-s)$,
$\Omega \geq 1 / 2$
(A5)
$\hat{w}_{i}=\left(a_{1}+\Gamma\right)^{-1}\left[\left(a_{1}+\Omega \Gamma\right) p+\Gamma(1-\Omega)\left(p^{*}+s\right)+a_{l} \theta\right]$,
$\hat{w}_{j}^{*}=\left(a_{l}+\Gamma\right)^{-1}\left[\left(a_{l}+\Omega \Gamma\right) p^{*}+\Gamma(1-\Omega)(p-s)+a_{l} \theta\right] ;$
(A6)

$$
w_{i}=\hat{w}_{i}{ }^{e}+b_{i}\left(q-q^{e}\right), \quad w_{j}^{*}=\hat{w}_{j}^{* e}+b_{j}^{*}\left(q^{*}-q^{* e}\right),
$$

where

$l_{i} \equiv \log$ of employment at firm $i, w_{i} \equiv \log$ of the nominal wage rate paid by firm $i$,

$p \equiv \log$ of the price level, $q \equiv \log$ of the consumer price index, and $s \equiv \log$ of the exchange

rate, measured in terms of units of domestic currency per unit of foreign currency.

Equations (A1) are the production functions of domestic firms $i$ and foreign firms $j$, equations (A2) are the implied labor demand schedules, and equations (A3) are the ex ante labor supply schedules. Equations (A4) define the consumer price indexes. Equations (A5) give the Walrasian, market-clearing wages that would arise in the absence of contracting, while equations (A6) are the contracted wages. Substituting the expectation of (A5) into (A6) and the result into (A2) and then into (A1) yields the expressions for equations (4c) and (4d) in the text, where $\alpha \equiv a_{0} a_{I}$ and where it has been assumed that the limiting case in which $\Gamma \rightarrow 0$ holds. (The model has been solved for the general case, but it is straightforward to show that this latter assumption simplifies the exposition greatly without altering the 
fundamental nature of the conclusions of the paper.) With full information and symmetric economies, solution of the model also yields the expressions for $\hat{y}$ and $\hat{y}^{*}$ that are given in the text. 


\section{APPENDIX B}

$$
\begin{aligned}
& A_{11}=\alpha(1-b)\left\{\delta\left[1+\alpha\left(1-b^{*}\right)\right]+\alpha b^{*}(1-\Omega)^{2}\right\} \\
& A_{12}=\alpha^{2} b\left(1-b^{*}\right)(1-\Omega)^{2} \\
& A_{13}=\alpha b \delta(1-\Omega)\left[1+\alpha\left(1-b^{\circ}\right)\right] \\
& A_{14}=(1+\alpha)\left\{\delta\left[1+\alpha\left(1-b^{*}\right)\right]+\alpha(1-\Omega)^{2}\left(b+b^{0}\right)\right\} \\
& A_{21}=\alpha^{2} b^{*}(1-b)(1-\Omega)^{2} \\
& A_{22}=\alpha(1-b)\left\{\delta[1+\alpha(1-b)]+\alpha b(1-\Omega)^{2}\right\} \\
& A_{23}=\alpha b^{*} \delta(1-\Omega)[1+\alpha(1-b)] \\
& A_{24}=(1+\alpha)\left\{\delta[1+\alpha(1-b)]+\alpha(1-\Omega)^{2}\left(b+b^{0}\right)\right\} \\
& A_{31}=\alpha\left\{\delta(1-b)+\alpha(1-\Omega)\left[1-\Omega\left(b+b^{*}\right)+(2 \Omega-1) b b^{*}\right]\right\} \\
& A_{32}=\alpha^{2}(1-\Omega)^{2} b\left(1-b^{*}\right)^{2} \\
& A_{33}=(1+\alpha)\left\{\delta+\alpha(1-\Omega)\left[1+b-\Omega\left(b+b^{*}\right)\right]\right\} \\
& A_{41}=\alpha\left\{\delta\left(1-b^{*}\right)+\alpha(1-\Omega)\left[1-\Omega\left(b+b^{*}\right)+(2 \Omega-1) b b^{*}\right]\right\} \\
& A_{42}=\alpha\left(1-b^{j}\right)\left\{\delta[1+\alpha(1-b)]+\alpha b(1-\Omega)^{2}\right\} \\
& A_{43}=(1+\alpha)\left\{\delta\left[1+\alpha\left(b^{*}-b\right)\right]+\alpha(1-\Omega)\left[\left(1+b-\Omega\left(b+b^{j}\right)\right]\right\}\right. \\
& A_{51}=\delta+\alpha(1-\Omega)[1+b-\Omega(b+b)] \\
& A_{52}=\alpha^{2} b\left(1-b^{*}\right)(1-\Omega)^{2} \\
& A_{53}=(1+\alpha) A_{51} \\
& A_{61}=\delta+\alpha(1-\Omega)\left[1+b^{*}-\Omega\left(b+b^{*}\right)\right] \\
& A_{62}=\delta[1+\alpha(1-b)]+\alpha(1-\Omega)^{2}\left[b+b^{*}+\alpha b^{*}(1-b)\right] \quad A_{63}=(1+\alpha) A_{61} \\
& \mathrm{~B}_{11}=\alpha(1-\Omega)^{2}\left[1+b^{*}+\alpha\left(1-b^{*}\right)\right]+\delta\left[1+\alpha\left(1-b^{*}\right)\right] \quad \mathrm{B}_{12}=\alpha(1+\alpha)\left(1-b^{*}\right)(1-\Omega)^{2} \\
& \mathrm{~B}_{13}=\delta[1+\alpha(1-\Omega b)]\left[1+\alpha\left(1-b^{*}\right)\right]+\alpha \Omega(1-\Omega)^{2}\left[b+b^{*}+\alpha\left(b+b^{*}-2 b b^{*}\right)\right] \\
& \mathrm{B}_{14}=\alpha(1-\Omega)\left\{(1-\Omega)^{2}\left[b+b^{*}+\alpha\left(b+b^{*}-2 b b^{*}\right)\right]-\delta b\left[1+\alpha\left(1-b^{*}\right)\right]\right\} \\
& B_{15}=(1+\alpha)\left\{2 \alpha b^{*}(1-\Omega)^{2}+\delta\left[1+\alpha\left(1-b^{*}\right)\right]\right\} \quad B_{21}=\alpha(1+\alpha)(1-b)(1-\Omega)^{2} \\
& \mathrm{~B}_{22}=\alpha(1-\Omega)^{2}[1+b+\alpha(1-b)]+\delta[1+\alpha(1-b)] \\
& \mathrm{B}_{23}=\alpha(1-\Omega)\left\{(1-\Omega)^{2}\left[b+b^{*}+\alpha\left(b+b^{*}-2 b b^{*}\right)\right]-\delta b^{*}[1+\alpha(1-b)]\right\} \\
& B_{24}=a[1+\alpha(1-b)]\left[1+\alpha\left(1-\Omega b^{*}\right)\right]+\alpha \Omega(1-\Omega)^{2}\left[b+b^{*}+\alpha\left(b+b^{*}-2 b b^{*}\right)\right] \\
& \mathrm{B}_{25}=(1+\alpha)\left\{2 \alpha b(1-\Omega)^{2}+\delta[1+\alpha(1-b)]\right\} \quad \mathrm{B}_{31}=\delta+\alpha(1-\Omega)\left[1+b^{*}(1-2 \Omega)\right] \\
& B_{32}=\alpha(1+\alpha)(1-\Omega)^{2}\left(1-b^{*}\right) \\
& B_{33}=(1+\alpha)\left\{\delta+\alpha(1-\Omega)\left[1+b^{*}(1-2 \Omega)\right]\right\} \\
& B_{41}=\delta+\alpha(1-\Omega)[1+b(1-2 \Omega)] \\
& \mathrm{B}_{42}=\delta[1+\alpha(1-b)]+\alpha(1-\Omega)^{2}[1+b+\alpha(1-b)] \\
& B_{43}=(1+\alpha)\{\delta+\alpha(1-\Omega)[1+b(1-2 \Omega)]\} \\
& C_{11}=\frac{A_{31}}{\beta B_{31}} \\
& C_{12}=\frac{A_{42}}{\beta B_{42}}
\end{aligned}
$$




$$
\begin{array}{lr}
D_{11}=A_{13} A_{11}+\beta B_{13} B_{11} & D_{12}=A_{13} A_{11}+\beta B_{14} B_{11} \\
D_{21}=A_{23} A_{22}+\beta B_{23} B_{22} & D_{22}=A_{23} A_{22}+\beta B_{24} B_{22} \\
\Delta_{f}=\delta[1+\alpha(1-b)]\left[1+\alpha\left(1-b^{\circ}\right)\right]+\alpha(1-\Omega)^{2}\left[b+b^{*}+\alpha\left(b+b^{*}-2 b b^{*}\right)\right] & \\
\Delta_{m}=\delta[1+\alpha(1-b)]+\alpha(1-\Omega)\left[1+b-\Omega\left(b+b^{\circ}\right)\right]+\alpha^{2}(1-\Omega)\left[1-\Omega\left(b+b^{*}\right)+(2 \Omega-1) b b^{*}\right]
\end{array}
$$




\section{REFERENCES}

Abramowicz, Michael and Geoffrey Woglom, 1995, "Central Bank Independence and Output Stabilization: Evidence from Structural Vector Autoregressions," Working Paper, Amherst College.

Aizenman, Joshua, 1985, "Wage Flexibility and Openness," Quarterly Journal of Economics 100, 539-550.

Aizenman, Joshua and Frenkel, Jacob, 1985, "Optimal Wage Indexation, Foreign Exchange Intervention, and Monetary Policy", American Economic Review 75, 402-423.

Akhand, Hafiz, 1992, "Policy Credibility and Inflation in a Wage-Setting Game," Canadian Economic Journal 25, 407-419.

Ball, Laurence, 1988, "Is Equilibrium Indexation Efficient?" Quarterly Journal of Economics 103, 299-311.

Ball, Laurence and Stephen Cecchetti, 1991, "Wage Indexation and Discretionary Monetary Policy," American Economic Review 81, 1310-1319.

Barro, Robert J. and David Gordon, 1983, "Rules, Discretion and Reputation in a Model of Monetary Policy," Journal of Monetary Economics 12, 101-121.

Bruno, Michael and Jeffrey Sachs, 1985, The Economics of Worldwide Stagflation, Basil Blackwell, Oxford.

Calmfors, Lars and John Driffill, 1988, "Bargaining Structure, Corporatism, and Macroeconomic Performance," Economic Policy 3, 14-61.

Canzoneri, Matthew, 1985, "Monetary Policy Games and the Role of Private Information," American Economic Review 75, 1056-1070.

Cubitt, Robin, "Monetary Policy Games and Private Sector Precommitment," Oxford Economic Papers 44, 513-530.

Devereux, Michael, 1987, "The Effect of Monetary Variability on Welfare in a Simple Macroeconomic Model," Journal of Monetary Economics 19, 427-435.

Duca, John and David VanHoose, 1991, "Optimal Wage Indexation in a Multisector Economy," International Economic Review 32, 859-867.

Fethke, Gary and Richard Jackman, 1984, "Optimal Monetary Policy, Endogenous Supply, and Rational Expectations," Journal of Monetary Economics 13, 211-224.

Fischer, Stanley, 1977, "Long-Term Contracts, Rational Expectations, and the Optimal Money Supply Rule," Journal of Political Economy 85, 191-205. 
Flood, Robert P. and N. P. Marion, 1982, "The Transmission of Disturbances under Alternative Exchange-Rate Regimes with Optimal Indexation," Quarterly Journal of Economics 97, 43-66.

Giavazzi, Francesco and Alberto Giovannini, 1989, "Monetary Policy Interactions under Managed Exchange Rates", Economica 56, 199-213.

Gray, Jo Anna, 1976, "Wage Indexation: A Macroeconomic Approach," Journal of Monetary Economics 2, 221-235.

Hardouvelis, Gikas, 1987, "Optimal Wage Indexation and Monetary Policy in an Economy with Imported Raw Materials," Journal of International Money and Finance 6, 419-432.

Hardouvelis, Gikas, 1992, "Monetary Policy Games, Inflationary Bias, and Openness," Journal of Economic Dynamics and Control 16, 147-164.

Jensen, Henrik, 1993, "International Monetary Policy Cooperation in Economies with Centralized Wage Setting," Open Economies Review 4, 269-285.

Marston, Richard, 1982, "Wages, Relative Prices, and the Choice Between Fixed and Flexible Exchange Rates," Canadian Economic Journal 15, 87-103.

Milesi-Ferretti, Gian Maria, 1994, "Wage Indexation and Time Consistency: A Note," Journal of Money, Credit, and Banking 26, 941-952.

Rasmussen, Bo Sandemann, 1993, "Exchange Rate Policy, Union Wage Indexation, and Credibility," Journal of International Economics 35, 151-167.

Rogoff, Kenneth, 1985, "Can International Monetary Policy Cooperation be Counterproductive?" Journal of International Economics 18, 198-217.

VanGompel, J., 1994, "Stabilization with Wage Indexation and Exchange Rate Flexibility," Journal of Economic Surveys 8, 251-281.

VanHoose, David and Christopher Waller, 1989, "Islands, Indexation, and Monetary Policy," Economic Inquiry 27, 705-717.

VanHoose, David and Christopher Waller, 1991, "Discretion, Wage Indexation, and Inflation," Southern Economic Journal 58, 356-367.

Waller, Christopher and David VanHoose, 1992, "Discretionary Monetary Policy and Socially Efficient Wage Indexation," Quarterly Journal of Economics 107, 451-460.

Zandamela, Rogerio, 1988, "The Macroeconomic Implications of Wage Indexation in a TwoSector Open Economy," Weltwirtschaftliches Archiv 124, 269-285. 